\title{
Implementasi Mengasihi Allah Sesuai Markus 12:30 Pada Mahasiswa Sekolah Tinggi Teologi Bethany Surabayaa
}

\author{
Julianus Zaluchu \\ Evangelical Theological Seminary of Indonesia - Surabaya \\ E-mail: julianuszaluchu@sttii-surabaya.ac.id
}

\begin{abstract}
In this dissertation the researcher takes the title: Implementation Loves God In Mark 12:30 Among Students of Bethany High School Theology Surabaya. Students from Bethany High School Surabaya come from various backgrounds. This background colored the implementation and practice of loving God in Mark 12:30. In the field observation there is a negative phenomenon among students STT Bethany Surabaya in the implementation of loving God in Mark 12:30. In the formulation of the problem, the researcher determines from the four aspects of God's love in Mark 12:30, which aspect dominantly forms the implementation of loving God in the lives of STT Bethany Surabaya students.
\end{abstract}

The temporary answer to the problem under investigation, whose truth needs to be tested empirically is the hypothesis. Based on the formulation of the problem, the study of the theory and framework of the above hypothetical proposed as follows: 1. Loving God with all the heart in Mark 12:30 among students STT Bethany tend to be in low to moderate position, 2. Loving God with all the soul in Mark 12:30 among the students of STT Bethany tends to be in low to moderate positions. 3. Loving God with all the intellect in Mark 12:30 among the students of STT Bethany tends to be on the way to high. 4. Loving God with all the strength in Mark 12:30 amongst the students of STT Bethany tends to be in a position of being heading high.

The research methodology is quantitative with confirmatory explanatory approach that is based on quantitative in data collection and analysis to test the hypothesis specified. In this section of analysis and discussion of researchers conducted a discussion of the results of research hypotheses. The first hypothesis is that the application of the $Y$ variable tends to be in a moderate position. The findings in the field regarding the application of variable $Y$ are in a moderate position.

The hypothesis is acceptable. Based on the results of statistical tests on the implementation of variable $Y$ in the range of Lower Bound and Upper Bond value of $341.28 \mathrm{~s} / \mathrm{d} 347.85$ lies in the category is. Test the second hypothesis of implementation Loving God in Mark 12:30 among students STT Bethany the determining dimension is with all soul. The third hypothesis test is to love God in Mark 12:30 among students Bethany $(Y)$ STT is in accordance with the hypothesis is from low to medium.

Based on the above findings, the researcher proposes some practical implications that can be constructive input for STT Bethany Surabaya institution. The results of this study can be used by leaders and alumni STT Bethany to improve the quality of students in realizing loving God with all heart, soul, mind and strength.

Keywords: Death Ceremony, Evangelism, Salvation

\section{PENDAHULUAN}

Konsep mengenai cara Allah berkomunikasi memberikan sebuah dunia yang berbeda dari dunia di mana manusia modern sedang bergumul. Ini berarti bahwa manusia tidak perlu lagi menghancurkan, juga tidak perlu tenggelam di dalam sikapapatis; ada alasan untuk hidup, membangun, dan mengasihi. ${ }^{1}$ Manusia tidak lagi terombang-ambing. Kita dapat menunjukkan betapa berbedanya kedua dunia tersebut dengan memikirkan makna kasih.

\footnotetext{
${ }^{1}$ Schaeffer, Allah Yang Ada di Sana. The GOd Who Is There (Jakarta: Momentum, 2012), 137 
Manusia modern dengan cukup tepat memandang konsep kasih sebagai konsep yang sangat penting ketika ia mengamati personalitas. ${ }^{2}$ Akan tetapi, ia menghadapi sebuah persoalan yang sangat nyata mengenai makna kasih. Walaupun manusia modern mencoba menggantungkan segala sesuatu pada kata kasih, namun kasih dapat dengan mudah merosot menjadi sesuatu yang jauh lebih kecil karena manusia tidak benar-benar memahaminya.

Ia tidak memiliki universal yang memadai bagi kasih. ${ }^{3}$ Mengasihi Allah adalah salah satu aspek terpenting di dalam kehidupan beragama secara umum dan khususnya dalam pertumbuhan rohani seseorang. Semua agama mengajarkan bahwa mengasihi Tuhan merupakan kewajiban pemeluk agama. $^{4}$

Oleh sebab itu banyak cara yang dilakukan oleh orang percaya untuk memerlihatkan wujud kasih tersebut kepada Allah. Ada anggapan yang mengajarkan bahwa cukup dengan perbuatan baik. Karena itu ekspresi mengasihi Allah sudah dapat terwakilkan. Persoalan yang muncul dari tindakan semacam itu adalah orang-orang berlomba untuk melakukan perbuatan baik di dunia demi memerlihatkan rasa kasihnya kepada Tuhan, Allahnya. ${ }^{5}$

Penekanan pada perbuatan baik telah menjadikan tindakan tersebut jauh lebih penting daripada menjalankan ibadah atau membangun kehidupan rohani yang lebih baik. Konsepnya adalah tidak perlu harus taat beribadah, juga tidak perlu terlihat terlalu rohani di dalam dunia ini. Asalkan tetap berbuat baik maka sikap seperti itu dianggap telah mencerminkan ekspresi mengasihi Allah. Konsekuensinya adalah orang bisa saja melakukan perbuatan baik dengan tetap berdosa karena beranggapan telah mengasihi Allah melalui perbuatannya menolong dan mengasihi sesama. Bahkan orang termotivasi melakukan perbuatan baik di depan umum demi terlihat memiliki kehidupan rohani yang mengasihi Allah. ${ }^{6}$

Selain itu wujud mengasihi Allah juga sering diperlihatkan melalui cara menjalankan ibadah yang sangat ketat. Pendapat ini didapatkan dari hasil wawancara kepada beberapa mahasiswa. ${ }^{7}$
Dengan pandangan di atas orang beranggapan bahwa melalui ibadah yang dilakukan secara khusyuk, penuh dengan aturan tata cara, taat kepada aturan-aturan agama, telah memerlihatkan di depan orang lain betapa rohaninya seseorang, telah menjalankan ibadahnya dengan baik dan ketat sebagai ekspresi telah mengasihi Allah.

Bahkan menganggap bahwa mengasihi Allah dengan segenap hati telah dilakukan dengan sebaik mungkin bila telah menjalankan ibadah dengan baik dan mampu menjalankan hubungan pribadi melalui doa dengan sungguh-sungguh.

Ketika mengungkapkan mengasihi Allah dengan segenap jiwa tercermin dari kehidupan mereka yang tidak emosional bahkan menunjukkan sikap yang baik dan menghindri adanya perbedaan karakter di antara mereka.

Dengan segenap akal budi tampak melalui kesungguhan mereka di dalam mengikuti pelajaran dan renungan-renungan firman Tuhan tetapi mereka tidak melaksanakan dengan baik.

Dengan segenap kekuatan mahasiswa berorientasi kepada fisik yang kuat namun sesungguhnya kehidupan mereka sangat lemah bahkan sering mengalami kendala di dalam penyakit. ${ }^{8}$ Akibat lebih lanjut adalah orang-orang berfokus mementingkan kegiatan ibadah daripada membangun kehidupan rohani yang sesungguhnya dan orang percaya terjebak kepada hal-hal yang bersifat agamawi. Itulah sebabnya Yesus melontarkan kritik yang cukup tajam kepada kaum Farisi sewaktu mengajar mengenai bagaimana seharusnya menjalankan kewajiban agama yang sejati.

Menurut Louis Berkhof, ketika kebaikan Allah diterapkan pada makhluk-Nya yang memiliki rasio, maka kebaikan Allah itu mengasumsikan satu karakter kasih yang lebih tinggi, dan kasih ini dapat dibedakan lagi menurut objek kasih itu. ${ }^{9}$

\footnotetext{
${ }^{2}$ Ibid.

${ }^{3}$ Ibid, 138

${ }^{4}$ Packer, Knowing God. Tuntunan Prakits UntukMengengal Allah (Yogyakarta: Andi Offset, 2008), 150

${ }^{5}$ Ibid.

${ }^{6}$ Ibid, 151

${ }^{7}$ Hasil Wawancara dengan mahasiswa Semester 1,3,5
} tahun 2017

\footnotetext{
8 Hasil Wawancara dengan Ibu Dorce Sondopen (dosen STT Bethany), 22 Februari 2018 (diperbaharui).

9 Berkhof, Teologi Sisematika: Doktrin Allah,
} (Surabaya: Momentum, 2005), 118 
Ia mengasihi makhluknya yang mempunyai rasio demi diri-Nya sendiri, atau untuk menyatakan dengan cara lain, Ia mengasihi dalam mereka DiriNya, kebaikan-Nya, karya-Nya, dan anugerah-Nya. Allah bahkan tidak menarik sama sekali kasih-Nya atas orang berdosa dalam keadaan mereka yang berdosa sekarang ini. ${ }^{10}$

Pada saat yang sama juga Ia mengasihi orang percaya dengan kasih yang khusus, sebab Ia telah mengasihi menjadikan mereka anak-anakNya di dalam Kristus. Kepada merekalah Ia mengkomunikasikan diri-Nya dalam arti yang

paling kaya dan penuh, dengan segala kepenuhan anugerah dan kemurahan-Nya (Yoh 16:27; Roma 5:8; 1 Yoh 3:1). ${ }^{11}$

Dengan terlihat aktif melayani, dengan terlihat banyak membantu pekerjaan Tuhan dalam hal tenaga dan uang, dengan terlihat sungguhsungguh beribadah, seseorang bisa mengklaim dirinya telah mengasihi Allah. Bahkan orang lainpun bisa menganggap bahwa seseorang sungguh mengasihi Tuhan karena telah memberikan hidupnya untuk melayani-Nya. Kenyataan tersebut memunculkan anggapan umum bahwa mengasihi Allah dengan segenap hati dapat diwujudkan dengan sebuah tindakan berbuat baik kepada orang lain, melayani Allah atau melaksanakan ibadah agama.

Muncul satu perkembangan menarik. Seiring dengan berkembangnya teologi kemakmuran, di dalam dekade terakhir, terlihat suatu sikap demonstratif di kalangan gereja-gereja beraliran karismatik, di mana tindakan mengasihi Allah dikaitkan secara langsung dengan tindakan memberi kepada-Nya. ${ }^{12}$ Terjadi penambahan di mana makna mengasihi Allah bukan hanya berkaitan soal perbuatan baik atau sikap beribadah, melainkan juga dalam hal memberi kepada Allah, tanpa mengesampingkan bahwa memang terdapat orangorang dengan sikap hati yang benar di dalam pemberian kepada Allah.

Dalam konsep itu, jemaat diminta untuk memersembahkan korban terbaik kepada Allah, berupa uang dan harta, sebagai benih pekerjaan Tuhan dengan satu keyakinan bahwa benih tersebut akan kembali dituai tigapuluh, enampuluh, seratus bahkan berlipat kali ganda. Maka yang terjadi adalah orang-orang berlomba-lomba menabur dalam jumlah yang sangat besar berupa uang kolekte atau persembahan spontan, demi mendapatkan hasil yang berlipat ganda pula. Orang yang memberi persembahan terbesar atau terbanyak dianggap lebih mengasihi Allah dibanding orang lain yang memberi sedikit. Demikian juga dalam hal perpuluhan. Seseorang yang dengan taat mengembalikan perpuluhan dianggap mengasihi Allah sebab dirinya taat kepada apa yang ditetapkan Allah. ${ }^{13}$

Di dalam Perjanjaian Lama, ketentuan mengasihi Allah adalah perintah Allah kepada bangsa Israel. Pada waktu itu, bangsa Israel dibawa keluar dari Mesir dan selama perjalanan mereka di padang gurun, Allah memberikan sejumlah ketentuan yang mengatur perilaku mereka di dalam berhubungan dengan Allah yang telah membebaskan mereka dari penindasan. Ketentuan tersebut tentu saja memiliki hubungan langsung dengan apa yang telah Allah lakukan pada mereka.

Sebelum keluar dari Mesir, bangsa Israel telah lama menjadi budak untuk membangun kota-kota bagi Firaun. Mereka secara fisik tertindas dan kehilangan kemerdekaan. Kebutuhan fisik mereka tersedia secara terbatas. Secara rohani bangsa yang terpilih ini tidak lagi mampu membangun hubungan dengan Allah nenek moyang mereka. Maka dalam sebuah kesempatan pascakeluar dari Mesir, untuk membangun kembali sebuah hubungan yang baru dengan Allah yang menjadi pembebas itu, bangsa Israel menerima sebuah standar baku tentang hukum-Nya, aturan-Nya, yang mengatur bagaimana seharusnya perilaku sebuah bangsa terpilih dan nilai-nilai apa yang harus ada di dalam diri mereka. ${ }^{14}$ Salah satu aspek terpenting di dalam standar baku itu adalah mengasihi Allah dan hal itu dihubungkan dengan hati, jiwa, dan kekuatan.

\footnotetext{
${ }^{10}$ Ibid.

${ }^{11}$ Ibid., 119.

${ }^{13}$ Ibid, 124

${ }^{12}$ Herlianto, Teologi Kemakmuran (Bandung: Yabina,

14 Chuck Missler, Learn The Bible in 24Hours 2006), 123

(Jakarta: Visi Media, 2006), 82. 
Di dalam Imamat dikatakan secara tegas perintah Allah kepada bangsa Israel: "Kasihilah TUHAN, Allahmu, dengan segenap hatimu dan dengan segenap jiwamu dan dengan segenap akal budimu dan dengan segenap kekuatanmu" (Imamat $6: 5) .{ }^{15}$

Dalam pandangan Yesus, konsep mengasihi Allah sangat penting dan berada di atas segala-galanya. Bagi-Nya, mengasihi Allah bukanlah merupakan kewajiban agamawi yang diperlihatkan melalui perbuatan baik ataupun sikap menjalankan ibadah yang disiplin atau radikal. Mengasihi Allah juga bukan merupakan anjuran, tetapi merupakan sebuah ketentuan yang tidak bisa tidak harus dilaksanakan. Juga bukanlah sebuah ibadah yang dibuat-buat seperti orang Farisi lakukan.

Dalam memberi penjelasan kepada orangorang Farisi, Yesus mengingatkan standar Allah tentang bagaimana cara mengasihi Allah. Yesus mengutip apa yang paling mereka ketahui selama ini, yakni ketentuan di dalam Imamat 6:5. Yesus mengatakan, "Kasihilah Tuhan, Allahmu, dengan segenap hatimu dan dengan segenap jiwamu dan dengan segenap akal budimu dan dengan segenap kekuatanmu" (Markus 12:30). Kemudian Dia melanjutkan, hukum yang kedua, yang sama dengan yang pertama, ialah "Kasihilah sesamamu manusia seperti dirimu sendiri" (Markus 12:31). Tidak ada hukum lain yang lebih utama dari pada kedua hukum ini (Markus 12:31).

${ }^{15}$ Ayat ini terkenal sebagai bagian dari confession of faith bangsa Israel. Dikenal sebagai Shema Israel (Shema adalah bahasa Ibrani dari kata "dengarlah"). Shema adalah sebuah doa utama bangsa Israel, dan menjadi doa yang pertama kali diajarkan bagi seorang anak Israel yang mulai belajar. Shema merupakan nafas dari seorang Israel sejati sebagai pengakuan ketaatan terhadap Allah yang esa dan kecintaan yang luar biasa kepada-Nya, bahkan dibela sampai mati. Boleh ada allah yang lain tetapi bagi Israel hanya ada satu Allah dan Allah itu esa. Seorang Israel, ketika mengucapkan shema, maka hal itu merupakan pengakuan iman (confession of faith) yang bukan semata ucapan yang keluar dari mulut tetapi mengandung konsekuensi untuk menaati Allah dan taat melakukan segala perintah-Nya sepanjang hidup. Sebagai sebuah pengakuan iman, shema merupakan janji pribadi yang tetap setia kepada satu Allah. Orang Yahudi setidaknya membaca doa ini dua kali sehari saat pagi hari menjelang fajar dan sesaat sebelum beranjak tidur. Demikian juga saat menjelang kematian, seorang Yahudi memanjatkan doa shema Israel. Bagi seorang Yahudi Orthodoks, mereka membaca setiap kalimat shema dengan hati-hati di dalam rumah ibadah dan menutup mata dengan tangan kanan melambangkan penghayatan dan ketakutan akan Tuhan yang adalah Allah itu. Terdapat tiga bagian doa yang sangat terpenting, yaitu Shema (Ulangan 6:4-9), yang disebutkan sebagai pengakuan; Vehayah (Ulangan 11:13-21), yang terdapat di dalam mezuzah; dan Vahyomere (Bilangan 15:37-41), yang digunakan di tallit.
Penegasan Yesus tersebut sekaligus merupakan teguran keras bagi orang-orang Farisi yang menganggap bahwa hukum Taurat jauh lebih penting dan terutama, seperti yang selama itu mereka yakini dan ajarkan kepada masyarakat Israel. Bagi Yesus, melaksanakan hukum Taurat tidak akan berarti apa-apa dan tidak membawa perubahan jika orang yang melakukan itu tidak mengasihi Allah yang memberikan hukum itu dan di saat yang sama tidak memerlihatkan hal itu di dalam kualitas hubungannya dengan sesama manusia dalam bentuk kasih.

Berdasarkan apa yang dikemukakan oleh Yesus tersebut di atas, peneliti sependapat bahwa sebetulnya yang menjadi standar mengasihi Allah bukanlah seperti apa yang orang pikirkan selama ini, termasuk di dalamnya apa yang pernah dilakukan oleh orang Farisi, melainkan apa yang dikemukakan oleh Yesus sendiri, berdasarkan empat faktor penting yakni, (1) dengan segenap hati; (2) dengan segenap jiwa; (3) dengan segenap akal budi; dan (4) dengan segenap kekuatan. Keempat faktor tersebut harus dilakukan secara serentak di dalam kualitas dan kuantitas yang sama.

Tentu saja muncul masalah karena setiap orang memiliki kapasitas dan implementasi yang berbeda-beda mengenai bagaimana mengasihi Allah dengan segenap hati, atau bagaimana mengasihi Allah dengan segenap jiwa, atau dengan segenap akal budi, atau bagaimana mengasihi Allah dengan segenap kekuatan, atau bagaimana mengasihi Allah dengan keempatnya sekaligus.

Mengasihi Allah adalah sebuah tuntutan Allah yang harus terlihat di dalam diri setiap orang percaya secara umum dan secara khusus di dalam diri para mahasiswa STT Bethanys ebagai pelayan Tuhan. Sebagai seorang pelayan Tuhan, apapun yang dilakukan dalam rangka pelayanan di dalam gereja, haruslah merefleksikan kecintaan terhadap Tuhan dan bukan karena tuntutan pelayanan. Bukan berarti yang orang Farisi lakukan, bahwamereka melayani karena peraturan. Demikian halnya pada mahasiswa STT Bethany Surabaya yang berjumlah 150 orang. Di dalam pendidikan kepada para mahasiswa ditekankan untuk melayani Tuhan bukan melayani manusia. Untuk itu pelayanan apapun, haruslah merefleksikan kasih kepada Allah. 
Sehubungan dengan penjelasan Yesus mengenai kasih kepada Allah di atas, peneliti mengamati bahwa di kalangan para mahasiswa STT Bethany Surabaya masih ada pandangan atau implementasi yang berbeda dalam hal itu. Ada mahasiswa yang menganggap bahwa dirinya sudah benar-benar mengasihi Allah, tetapi perilakunya tidak mencerminkannya. Demikian juga, ada mahasiswa yang menganggap bahwa apa yang telah dilakukannya adalah sebuah cerminan kasih kepada Allah, sementara yang lain beranggapan bahwa kasih kepada Allah yang ada di dalam dirinya jauh lebih baik daripada yang ada di dalam diri sesama mahasiswa yang ada. Terlihat juga bahwa keempat aspek mengasihi Allah, yang Yesus tuntut dan kehendaki adalah sejajar dan serentak, tetapidipahami secara terpisah oleh para pelayan/mahasiswa. Mereka menganggap bahwa mengasihi Allah dengan segenap hati adalah jauh lebih penting dari tigaaspek lainnya. Adapula yang beranggapan bahwa mengasihi Allah cukup dengan memerlihatkannya dengan berbuat baik kepada sesama atau melalui respon aktif di dalam ibadahibadah gereja/pertemuan-pertemuan.

Bahkan ada pelayan/mahasiswa yang menganggap bahwa segala apa yang diperbuatnya di dalam mendukung pelayanan di institusi secara maksimal, baik dengan tenaga, waktu ataupun uang, telah merefleksikan kasih kepada Allah sesuai dengan yang Yesus maksudkan di dalam Markus 12:30 tersebut. *

Mahasiswa STT Bethany berasal dari berbagai latar belakang yang berbeda-beda. Mereka berasal dari tempat yang berbeda, latar belakang pendidikan yang berbeda, keluarga yang berbeda, umur yang berbeda, asal gereja yang berbeda. ${ }^{16}$ Besar kemungkinan latar belakang itu juga mewarnai implementasi dan praktik mengasihi Allah seharihari yang dimaksud dalam Markus 12: 30.

Berdasarkan uraian tersebut di atas dan temuan di lapangan, peneliti menyimpulkan bahwa implementasi dan praktik mengasihi Allah di kalangan para mahasiswa STT Bethany adalah berbeda-beda, baik dari sisi kualitas maupun kuantitas jika dibandingkan dengan maksud Yesus di dalam Markus 12:30. Aspek-aspek mengasihi Allah dengan segenap hati, jiwa, akal budi, dan kekuatan dilakukan terpisah satu dengan lainnya.
Kenyataan inilah yang kemudian melatarbelakangi peneliti untuk melihat dan mendalami bagaimanakah sebetulnya kecenderungan para mahasiswa STT Bethany Surabaya di dalam mengasihi Allah seperti tertulis dalamMarkus 12:30. Penelitian ini juga berusaha mengungkap hal-hal dominan apa saja yang membentuk perilaku para mahasiswa STT Bethany Surabaya di dalam mengasihi Allah menurut Markus 12:30 tersebut.

\section{Fokus Penelitian}

Pertama. Ada fenomena negatif di kalangan para mahasiswa STT Bethany Surabaya bahwa masih ada pandangan atau implementasi yang berbeda dalam hal mengasihi Allah dalam Markus 12: 30. Ada mahasiswa yang menganggap bahwa dirinya sudah benar-benar mengasihi Allah, tetapi perilakunya tidak mencerminkannya. Demikian juga, ada mahasiswa yang menganggap bahwa apa yang telah dilakukannya adalah sebuah cerminan kasih kepada Allah, sementara yang lain beranggapan bahwa kasih kepada Allah yang ada di dalam dirinya jauh lebih baik daripada yang ada di dalam diri sesama mahasiswa yang ada.

Terlihat juga bahwa keempat aspek mengasihi Allah, yang Yesus tuntut dan kehendaki adalah sejajar dan serentak, tetapi dipahami secara terpisah oleh para pelayan/mahasiswa. Mereka menganggap bahwa mengasihi Allah dengan segenap hati adalah jauh lebih penting dari tiga aspek lainnya. Adapula yang beranggapan bahwa mengasihi Allah cukup dengan memerlihatkannya dengan berbuat baik kepada sesama atau melalui respon aktif di dalam ibadah-ibadah gereja/pertemuanpertemuan. Bahkan ada pelayan/mahasiswa yang menganggap bahwa segala apa yang diperbuatnya di dalam mendukung pelayanan di institusi secara maksimal, baik dengan tenaga, waktu ataupun uang, telah merefleksikan kasih kepada Allah sesuai dengan yang Yesus maksudkan di dalam Markus 12:30 tersebut 
Kedua. Selain ada implementasi yang berbeda secara keseluruhan tentang mengasihi Allah dalam Markus 12: 30, didapati pula implementasi tentang adanya praktik mengasihi Allah tersebut. Ada implementasi bahwa mengasihi Allah cukup menekankan satu aspek yang dianggap lebih penting dari aspek-aspek lainnya. Sebagai contoh ada mahasiswa yang menganggap bahwa mengasihi Allah dengan segenap hati adalah jauh lebih penting dari tiga aspek lainnya. Adapula yang beranggapan bahwa mengasihi Allah cukup dengan memerlihatkannya dengan berbuat baik kepada sesama atau melalui respon aktif di dalam ibadahibadah gereja/pertemuan-pertemuan. Bahkan ada pelayan/mahasiswa yang menganggap bahwa segala apa yang diperbuatnya di dalam mendukung pelayanan di institusi secara maksimal, baik dengan tenaga, waktu ataupun uang, telah merefleksikan kasih kepada Allah sesuai dengan yang Yesus maksudkan di dalam Markus 12:30.

Ketiga. Didapati kenyataan bahwa Mahasiswa STT Bethany berasal dari berbagai latar belakang yang berbeda-beda. Mereka berasal dari tempat yang berbeda, latar belakang pendidikan yang berbeda, keluarga yang berbeda, umur yang berbeda, asal gereja yang berbeda. ${ }^{17}$

Besar kemungkinan latar belakang itu juga mewarnai implementasi dan praktik mengasihi Allah sehari-hari yang dimaksud dalam Markus 12: 30. Setelah belajar di STT Bethany semestinya mereka mengasihi Allah secara benar dalam hidup seharihari dan pelayanan seperti yang dimaksud dalam Markus 12:30.

\section{Rumusan Masalah}

Pertama. Bagaimanakah implementasi para mahasiswa STT Bethany tentang mengasihi Allah dalam Markus 12:30?

Kedua. Dari empat aspek kasih Allah dalam Markus 12: 30 itu aspek manakah yang dominan membentuk implementasi mengasihi Allah dalam hidup para mahasiswa STT Bethany Surabaya?

Ketiga. Dari aspek latar belakang mahasiswa STT Bethany Surabaya, aspek manakah yang dominan membentuk implementasi mengasihi Allah dalam Markus 12: 30?

\section{Tujuan Penelitian}

Pertama. Untuk mengetahui implementasi para mahasiswa STT Bethany tentang mengasihi Allah dalam Markus 12: 30.Kedua. Untuk memeroleh informasi, dari empat aspek mengasihi Allah dalam Markus 12: 30 itu aspek manakah yang dominan membentuk implementasi mengasihi Allah dalam hidup para mahasiswa STT Bethany Surabaya? Ketiga. Untuk menemukan aspek latar belakang mahasiswa STT Bethany Surabaya yang dominan membentuk implementasi mengasihi Allah dalam Markus 12: 30 ?

\section{Kepentingan Penelitian}

Kepentingan Teoritis:

Pertama, hasil penelitian ini memberikan kontribusi dalam dunia pendidikan teologi mengenai pengajaran tentang mengasihi Allah dalam Markus 12: 30 dalam kehidupan orangorang percaya. Kedua, penelitian ini akan memerluas wawasan para hamba Tuhan tentang Implementasi mengasihi Allah dalam Markus 12:30. Ketiga, penelitian ini membangun implementasi para hamba Tuhan tentang Implementasi Mengasihi Allah dalam Markus 12:30.

Kepentingan Praktis: Pertama, hasil penelitian ini dapat menjadi pedoman bagi para hamba Tuhan untuk mengajar jemaat tentang Implementasi Mengasihi Allah dalam Markus 12:30.

Kedua, hasil penellitian ini dapat menjadi pedoman untuk menjawab isu-isu yang muncul di sekitar 5 pokok di atas. Ketiga, hasil penelitian ini dapat dijadikan informasi bagi para hamba Tuhan guna meningkatkan implementasi mengasihi Allah dalam Markus 12:30.

\section{Implementasi Mengasihi Allah}

Mengasihi Allah adalah sebuah perintah Allah di mana manusia tidak memiliki pilihan selain menaatinya. Untuk melaksanakan perintah tersebut, Allah menuntut bukan hanya terbatas pada pengakuan dan ritual keagamaan tertentu melainkan, melibatkan sebuah tindakan yang lahir dari kesadaran rohani bahwa tindakan mengasihi Allah

\footnotetext{
${ }^{17}$ Sumber dari dokumen wawancara dan dokumen pendaftaran seleksi masuk STT Bethany.
} 
tersebut merupakan kebutuhan Allah di dalam diri manusia ciptaan-Nya. Salah satu hal penting di dalam mengasihi Allah adalah melakukannya secara keseluruhan dan melibatkan semua unsur yang diperlukan dalam rangka mengasihi Allah yang dalam hal ini segenap hati, jiwa, akal budi dan kekuatan.

Akan tetapi ekspresi mengasihi Allah sering terlihat tidak sama dikalangan para pelayan baik dalam hal pengertian maupun aplikasinya. Hal ini bisa disebabkan karena ketidaksamaan pemahaman dan tidak adanya standar yang jelas di dalam mengasihi Allah sesuai dengan ajaran Yesus di dalam Markus 12:30

Berdasarkan uraian tersebut di atas, sekalipun berbeda-beda di dalam pemahaman dan perilaku, patut diduga bahwa mahasiswa STT Bethany memiliki konsep cenderung mengasihi Allah di dalam diri mereka. Dengan adanya pemahaman yang tidak benar mengenai kasih kepada Allah maka ekspresi mengasihi Allah di kalangan mahasiswa STT Bethany akan rendah.

Setelah melakukan kajian, baik kajian teori maupun analisis data penelitian pada empat dimensi maka didapatkan bahwa tingkat kecenderungan penerapan masing-masing dimensi di antara mahasiswa STT Bethany berada pada katagori sedang.

Namun ini dapat dijadikan maksimal bila masing-masing dimensi dapat diberdayakan secara maksimal.

\section{Kepustakaan}

[1] Alkitab Terjemahan Baru (c) 1974 Lembaga Alkitab Indonesia

[2] Abineno, J.L. Ch. Seksualitas dan Pendidikan Seksual. Jakarta: BPK Gunung

Mulia, 2000

[3] Achtemeier, Paul J. (Ed.) Harper Collins Bible Dictionary. New York : Harper

Collins Pubblise, 1996

[4] Adams, Jay E. Sheperding God's Flock: The Pastoral Life. USA: Presbyterian and

Refomed Publishing Company, 1975

[5] Allen, Clifton J. (edited by), The Broadman Bible Commentary- Volume 6

Matthew - John. Nashville, Tennessee: Broadman Press, 1970.

[6] Alexander, David dan pat Alexander. Handbook to the Bible - cetakan kedua.

Bandung : Kalam Hidup, 2004
[7] Anderson, Leith. Jesus : Biografi Lengkap

Tentang Pribadinya, Negara Nya dan

Bangsa-Nya. Yogyakarta : Gloria Graffa, 2008.

[8] Anthony, M. (edited by). Christian Education: Foundations for Twenty-first

Century. Grands Rapids, Michigan: Baker Academic, 2001

[9] Asmani, Jamal Ma'mu. Buku Panduan Internalisasi Pendidikan Karakter di

Sekolah. Jogyakarta: Diva Press, 2011.

[10] Badudu J.S., Sutan Muhammad Zain. Kamus Besar bahasa Indonesia Jakarta:

Sinar Harapan, 1996

[11] Bailey, Brian J. Pilar-pilar Iman. Jakarta: Nafiri Gabriel, 1996.

[12] Barclay, William. Duta Bagi Kristus. Jakarta: BPK Gunung Mulia, 1980.

[13] Baker, Kenneth L. (Ed) NIV Study Bible. Grand Rapids, Michigan : Zondervan, 2002.

[14] Baker, Kenneth L. and John Kohlenberger III (Ed.) Zondervan NIV Bible Commentary. Grand Rapid, Michigan: Zondervan Publishing, tt.

[15] Basser, Herbert W. Studies In Exegesis. Leiden : Brill, 2000.

[16] Baxter, J. Sidlow. Menggali Isi Alkitab: Matius s.d. Kisah Para Rasul. Jakarta: BPK Gunung Mulia dan YKBK/OMF, 1982.

[17] Berkhof, Louis. Teologi Sistematika: Doktrin Gereja. Surabaya: Momentum, 1997.

[18] Blanchard, John. Benar di Hadapan Allah. Bandung : Kalam Hidup, 1997.

[19] Bergant, Diane dan Robert J. Karris. Tafsir Alkitab Perjanjian Baru. Yogyakarta

Kanisius, 2002.

[20] Bolkestein, M.H Kerjaan Yang Terlebung. Jakarta : BPK Gunung Mulia, 1999

Borg, Marcus J. Kali Pertama Jumpa Yesus Kembali. Jakarta: BPK Gunung Mulia, 2000.

[21] Bouma, J. Kelakuan Yang Bertanggung Jawab: Pembimbing ke Dalam Etika

Kristen. Jakarta; BPK Gunung Mulia, 2000.

[22] Branca, Albert A. Psychology:The Science of Behavior. Boston: Allyn and Bacon. Inc, 1965.

[23] Brauch, Manfred T. Ucapan Paulus Yang Sulit, terj. Fenny Veronika. Malang: 
Departemen Literatur SAAT, 1999.

[24] Burke, John Soul Revolution. How Imperfect People Become All God Intende.

Grand Rapids : Zondervan, 2008

[25] Burridge, Richard A. Four Gospel One Jesus. Malang : Gandum Mas, 2008.

[26] Cadbury, Hendry J. The Book of Acts. New York: Harper \& Brothers Publishers,

1955.

[27] Carson, D.A Love In Hard Places. Surabaya : Momentum, 2007.

[28] Chapman, Adina. Pengantar Perjanjian Baru. Bandung: Yayasan Kalam Hidup,

2004.

[29] Cleveland, Donald. Seven Wonders of

Communication. Minneapolis: Twenty-

First Century Books, 2010.

[30] Conybeare, W.J. dan J.S. Howson, The Life and Epistles of St. Paul: A Classic

Work on the Life and Writings of the Great Missionary apostle. Grand Rapids

Michigan: Eerdmans Publishing Company, 1987.

[31] Cooper, Robert K., dan Ayman Sawaf. Executive EQ: Kecerdasan Emosional

dalam Kepemimpinan dan Organisasi. Jakarta: Gramedia, 2002.

[32] Covey, Stephen. Tujuh Kebiasaan Keluarga yang Efektif, Edisi Revisi Jakarta:

Mitra.

[33] Collins, Gerald, O. Christology A Biblical Historical and Systematic Study Of Jesus. United States : Oxford University Press, 2009.

[34] Colson. Charles Loving God. Jakarta : Pionir Jaya, 1996.

[35] Crano, William D. And Radmila Prislin, Attitudes and Attitude Change. London :

Psychology Press. 2008.

[36] Culpepper, R. Alan. Smyfh and Helwys Bible Commentary: Mark.

[37] Georgia:,Smyth \& Helwys Publishing, 2007.

[38] Eliezer, Sasmoko. Metode Penelitian Pengukuran dan Analisis Data.Jakarta:

HITS, 2005.

[39] Everitt, B.S. The Cambridge Dictionary of Statistics. New York: Cambridge

University Press, 2006.

[40] Gariepy, Henry. 100 Portraits of Christ. England: Scripture Press, 1988. Gray,

[41] James M. The Concise Bible Commentary. Peabody, Massachusetts:

Hendrickson Publisher, 1999.
[42] Gilbrant, Thoralf (Ed.). The New TestamentIntroduction Greek Grammar and Indices. Springfield: World Library Press, 1994.

[43] Guthrie, Donald. Pengantar Perjanjian Baru Volume 1. Surabaya: Momentum,

2008.

[44] Hastings, James (editor), Dictionary of The Bible, New York: Charles Scribner's

Sons, 1937.

[45] Henry, Matthew. Injil Markus. Surabaya: Momentum, 2007.

[46] Hills, P.J. Dictionary of Education. London: Routledge \& Keegan Paul, 1972

[47] Incigneri, Brian J. The Gospel to the Romans: The Setting and Rhetoric of

Mark's Gospel. Leiden: Koninklijke Brill nv, 2003. [48] Juanda, D. R. "Melayani Kristus Dengan Karya Tulis." Journal Kerusso 2.1

(2017): 45-54.

[49] Keene, Michael. Yesus. Yogyakarta: Kanisius, 2007.

[50] Keene, Michael. Alkitab: Sejarah, Proses Terbentuk dan Pengaruhnya.

Yogyakarta: Kanisius, 2006.

[51] Kempf-Leonard, Kimberly (Ed.). Encyclopedia of Social Measurement. Boston:

Elsevier, 2005.

[52] Kinlaw, Dennis F. The Mind of Christ. Yogyakarta: ANDI, 1998.

[53] Norman. The Shema - Spirituality and Law in Judaism. Philadephia: The Jewish

Publication Society, 2002.

[54] Lane, William L. The Gospel of Mark. Grand Rapids: Wm. B. Eerdmans, 1974.

[55] Lane, William The Gospel according to Mark. The New International

Commentary on the New Testament. Grand Rapids, Michigan: Wm. B. Eerdmans,

1974.

[56] Lewis-Beck, Michael (Ed.). Encyclopedia of Social Science Research

Methods.SAGE Publications. v Menken, Maarten J.J. dan Steve Moyise.

[57] Deuteronomy in The New Testament. London: T\&T Clark International, $\mathrm{ft}$.

[58] Missler, Dr. Chuck, Learn the Bible in 24 Hours. Jakarta: Visi Media, 2006.

[59] Owens, John Joseph. Analytical Key to the Old Testament. Grand Rapids,

Michigan: Baker Books, 1989.

[60] Newman, Barclay M. Kamus Yunani Indonesia, Jakarta: BPK Gunung Mulia, 
2010.

[61] Chaplin, J.P. Kamus Lengkap Psikologi. Jakarta: Rajawali, 1989.

[62] Pandensolang, Welly. Kristologi Kristen. Jakarta: YAI Press, 2009.

[63] Pandensolang, Welly. Gramatika dan Sintaksis

Bahasa Ibrani Perjanjian Lama.

Jakarta: YAI Press, 2009.

[64] Painter, John. Mark's Gospel. London: Raoutledge, 1997.

[65] Pasaribu, Marulak. Eksposisi Injil Sinoptik. Malang: Gandum Mas, 2005.

[66] Pfeiffer, Charles F. dan Everett F. Harrison, The Wycliffe Bible Commentary.

Malang: Gandum Mas, 2005.

[67] Permana, Surja, et al. "Correlation Study Of Church Leadership Towards Church

Member Commitment In Christian Church Of Indonesia Darmo Satelit Surabaya-

Jawa Timur." Sinergi: Jurnal Ilmiah Ilmu Manajemen 8.2 (2018).

[68] Rumiyati, Umi, et al. "Pengaruh Kepemimpinan Hamba Tuhan Dalam

Pertumbuhan Kerohanian Jemaat Gereja GPdI 'Zion'Krebet, Tembalang, Wlingi-

Blitar.

" Journal Kerusso 3.2 (2018): 9-19.

[69] Saldarini, Anthony J. Pharisees Scribes and Sadducees in Palestinian Society.

[70] Grand Rapids, Michigan: Wm. B. Eerdmans Publishing Company, 1988.

[71] Santoso, Singgih. Mastering SPSS 18. Jakarta: Elex Media Komputindo, 2010.

[72] Segal, Eliezer. Judaism. e-Book. Tk: tp, 2008.

[73] Sugiyono. Metode Penelitian Pendidikan. Bandung: Alfabeta, 2010. Sugiyono.

Statistika Untuk Penelitian. Bandung: Alfabeta, 2004.

[74] SwindoII,Charles R. So, You Want to be Like Chris \}? Delapan Hal Penting

Untuk Merealisasikannya. Bandung: Lembaga Literatur Baptis, 2008.

[75] Telford, W.R. The Theology of The Gospel of Mark. New York: Cambrigde

University Press, 1999.

[76] Thiessen, Henry C. Teologi Sistematika. Malang: Gandum Mas, 2008.

[77] Townsley, David (edited by), Scripture Index To The New International

Dictionary of New Testament Theology And Index To Selected Extrabiblical Literture.

Grand Rapids, Michigan: The Zondervan Corporation, 1985
[78] Unger, Merril F. The New Unger's Bible Dictionary. Chicago: Moody Press,

1966.

[79] Veith Jr, Geve Edward. Loving God with All Your Mind. Thinking as a

Christian in the Postmodem World. Wheaton:

Crossway Book, 2003.

[80] Veith Jr, Gene Edward. Dengan Segenap Akal Budi. Jakarta: BPK, 2003. Vine,

W.E. Vine's Expository Dictionary of Old and New testament Word. Nashville:

Thomas Nelson Publishers, 1997.

[81] Walsh, Brian J. dan Richard Middleton. Visi Yang Memperbaharui Pembentukan Cara Pandang Kristen. Jakarta: Reformed Institute Press, 2001. 